\title{
Çinko Tedavisi Ani İşitme Kaybında Etkili Olabilir mi?
}

Can Zinc Treatment Be Effective for Sudden Hearing Loss?

Erhan Arslan, Hasan Çanakçı

Balıkesir Üniversitesi Tip Fakültesi, Kulak Burun Boğaz Baş Boyun Cerrahisi

Anabilim Dalı,

Balıkesir, Türkiye

Correspondence:

Erhan ARSLAN

Balıkesir Üniversitesi Tip

Fakültesi, Kulak Burun Boğaz Baş

Boyun Cerrahisi Anabilim Dalı,

Balıkesir, Türkiye

e-mail: drarslanerhan@hotmail.com

\section{Özet}

Ani işitme kaybı (AİK) tedavisinde hem bir anti-inflamatuvar hem de bir antioksidan olan çinkonun etkinliğini araştırmaktır Bu çalışma etik kurul onayı alındıktan sonra retrospektif olarak üçüncü basamak sağlık kuruluşunda yapılmıştır. Çalışmaya 1865 yaş aralığında, AİK tedavisi için sistemik steroid ya da sistemik steroid ile birlikte çinko kullanılan hastalar dahil edilmiştir. Hastalar kullanılan tedavi çeşidine göre iki gruba ayrıldı. Tedavide sistemik steroid kullanılan hastalar Grup l'e, sistemik steroide ilave olarak çinko kullanılan hastalar ise Grup 2’ye dahil edildi. Tedavi etkinliğini değerlendirmek için işitme geri dönüş yüzdesi, işitme kazancı ve Furuhashi kriterleri kullanıldı. Grup 1 ve Grup 2 tedavi etkinliği açısından karşılaştırıldı. Çalışmaya, dahil edilme kriterlerini sağlayan Grup 1 de 40, Grup 2 de 36 olmak üzere toplam 76 hasta dahil edilmiştir. İki grup demografik verileri (yaş, cinsiyet), işitme kaybı geçirilen kulağın tarafı, işitme kaybına vertigo ve tinnitusun eşlik edip etmemesi, hastaların mevcut sistemik hastalıkları, ÜSYE varlığı ve işitme azlığı şikayetinin başlaması ile tedavi başlangıcı arasında geçen süre açısından karşılaştırıldığında, gruplar arasında istatistiksel olarak anlamlı fark saptanmadı. Grupların tedavi etkinliği; işitme kazançları, işitme geri dönüş yüzdeleri ve Furuhashi kriterleri kullanılarak karşılaştırıldı ve gruplar arasında her üç parametrede de istatistiksel olarak anlaml fark bulunmadı (sırasıyla $\mathrm{p}=0,815, \mathrm{p}=0,626, \mathrm{p}=0,853$ ). AİK tedavisinde sistemik steroide çinko eklenmesi sonucunda iyileşme parametrelerinde istatistiksel olarak anlamlı bir değişim saptanmamıştır. Çinkonun AİK tedavisinde günümüz koşullarında kullanımının gerekli olmadığını düşünmekteyiz.

Anahtar Kelimeler: Çinko; ani işitme kaybı; tedavi; antioksidan; anti-inflamatuvar

\section{Abstract}

To investigate the efficacy of zinc, which is both an anti-inflammatory and an antioxidant, in the treatment of sudden sensorineural hearing loss (SSNHL). The present study was carried out retrospectively at a territory reference center upon the approval of the local ethics committee. Patients between the ages of 18-65 who used systemic steroid or zinc with systemic steroids for the treatment of SSNHL were included in the study. The patients were divided into two groups according to the type of treatment used. The patients who used systemic steroids were included in Group 1, and the patients who used zinc in addition to systemic steroids were included in Group 2. Recovery rate, hearing gain, and Furuhashi criteria were used to evaluate the treatment efficacy. Group 1 and Group 2 were compared in terms of treatment efficiency. A total of 76 patients, 40 in Group 1 and 36 in Group 2, who met the inclusion criteria, were included in the study. When the two groups were compared in terms of demographic data (age, gender), side of the ear with hearing loss, whether the disease was accompanied by vertigo and tinnitus, the patients' existing systemic diseases, the presence of upper respiratory tract infection, and the time elapsed between the onset of hearing loss and the beginning of treatment, there was no statistically significant difference between the groups. Treatment efficacies of groups were compared using the hearing gain, recovery rate, and Furuhashi criteria, and there was no statistically significant difference in all three parameters between the groups. ( $p=0.815, p=0.626, p=0.853$, respectively). As a result of the addition of zinc to systemic steroid in SSNHL treatment, no statistically significant change was found in healing parameters. We think that it is not necessary to use zinc in the treatment of SSNHL in today's conditions.

Keywords: Zinc; sudden sensorineural hearing loss; treatment; antioxidant; anti-inflammatoryAnahtar Kelimeler: FISH, EGFR, CCND1, RREB1, malign melanom, melanositik nevüs 


\section{Giriș}

Ani işitme kaybı (AİK) son 72 saat içerisinde gelişen birbirini takip eden en az üç frekansta $30 \mathrm{~dB}$ ve üzeri sensörinöral işitme kaybı (SNIK) olarak tanımlanan bir otolojik acildir (1). AİK' nın tanı kriterleri net olsa da etyopatogenezi ile ilişkili çeşitli teoriler mevcuttur. Bunlar arasinda viral enfeksiyonlar, dolaşım bozuklukları, labirintin membran rüptürü, metabolik disfonksiyon, otoimmün ve reaktif oksijen türleri ile ilişkili koklear hasar sayılabilmektedir (2-4).

Günümüzdeki güncel tedavi k1lavuzlarında önerilen tedavi oral-intratimpanik steroidler ve hiperbarik oksijen tedavisidir $(5,6)$. Fakat AIK etyopatogenezinin net olarak belirlenememesi ve bu konudaki çeşitli teorilerden dolayı tedavi k1lavuzlarında önerilmese de steroidlere ilave olarak antiinflamatuvar ajanlar, antioksidanlar, kalsiyum antagonistleri, vazodilatatörler, vitaminler, eser elementler, volüm genişleticiler gibi çeşitli tedaviler hekimler tarafindan sıklıkla tercih edilmektedirler (7).

$\mathrm{Bu}$ tedavi seçenekleri arasında; insan eser elementlerinden olan hem bir antioksidan hem de bir anti-inflamatuvar olan çinkonun, iç kulak yapılarının temel komponentlerinden biri olduğu ve çinko düzeylerindeki eksikliğin işitme kayıplarına yol açabildiği gösterilmiş, çinko kullanımının AİK tedavisinde etkili olabileceği öne sürülmüştür (8-10).

Fakat bu konu ile ilgili literatürde yeterli çalışma bulunmamaktadır ve sonuçlar karşıtlıklar içermektedir. $\mathrm{Bu}$ sebeple çalıșmamızda AİK tedavisinde yalnızca sistemik steroid kullanımını ile sistemik steroide ek olarak çinko kullanımının hastaların işitme sonuçları üzerine olan etkisinin incelenmesi amaçlanmıştır.

\section{Gerec ve Yöntemler}

$\mathrm{Bu}$ retrospektif çalışma üçüncü basamak sağlık kuruluşunda, lokal etik kurul onayı alındiktan sonra (Etik kurul onay numarası: 2020/119) Helsinki Deklarasyonu'na uygun olarak gerçekleştirilmiştir. Çalışmaya 18- 65 yaş aralığında olan AİK tanısı ile tedavi edilmiş olan hastalar dahil edilmiştir.
Klinik bilgileri ve demografik verileri eksik olan hastalar, tedavisinde sistemik steroid ve çinko dışında diğer tedavi yöntemleri(örneğin intratimpanik steroid(hem çalışma ve kontrol gruplarındaki homojeniteyi bozabileceği hem de klinik yaklaşımımız gereği daha çok salvaj olarak kullanıldığı için) kullanılan hastalar, Meniere hastalığı, bilateral işitme kaybı, akustik travma öyküsü olan hastalar, serebellopontin köşe patolojisi saptanan hastalar, ototoksik ilaç kullanmış olan hastalar, laboratuvar tetkikleriyle otoimmün ya da enfeksiyöz bir patoloji saptanan hastalar, kafa travması geçirmiş olan hastalar çalışma dişı tutuldu.

Hastaların yaşları, cinsiyetleri, sistemik hastalıkları (diabates mellitus (DM), hipertansiyon (HT), son 1 hafta içinde geçirilmiş üst solunum yolu enfeksiyonu (ÜSYE) öyküsü olup olmamas1), odyolojik tetkik sonuçları (tedavi öncesi ve tedavi sonrası saf ses odyometri sonuçları, işitme kaybı olan kulağın tarafı) ve diğer klinik bilgileri (işitme kaybının başlangıç zamanı ile tedavi başlanması arasında geçen süre, eşik eden vertigo ve tinnitus şikâyeti) hastaların medikal kayıtlarından elde edildi ve kaydedildi.

İşitme kaybı şikâyeti ile başvuran ve AİK tanis1 konulan hastalara hastaneye yatarak AİK kılavuzlarına uygun olarak tedavileri başlanmıştır. Hastaların şikâyet başlama zamanları ve kaçıncı günde tedaviye başlandığı, tedaviye başlama zamanı kaydedilmiştir. Hastalar uygulanmış olan tedavi şekline göre iki gruba ayrıldı. Birinci gruba (Grup 1) (Steroid grubu) $1 \mathrm{mg} / \mathrm{kg}$ intravenöz olarak başlanıp takiben her 3 günde bir $20 \mathrm{mg}$ azalarak sonlandırılacak şekilde sistemik steroid (metilprednizolon) tedavisi verilen hastalar dâhil edildi (5). İkinci gruba (Grup 2) (Steroid + çinko grubu) ise yine $1 \mathrm{mg} / \mathrm{kg}$ intravenöz olarak başlayıp takiben her 3 günde bir $20 \mathrm{mg}$ azalarak sonlandırılacak şeklide sistemik steroid (metilprednizolon) tedavisi ve buna ilave olarak 1 ay süre ile günde $1 \mathrm{kez} 50 \mathrm{mg}$ çinkoya eşdeğer $137,3 \mathrm{mg}$ çinko sülfat monohidrat (Zinco $50 \AA$ mg Kapsül) oral olarak kullanan hastalar dahil edildi. 


\section{İşitmenin değerlendirilmesi}

Hastaların işitme değerlendirmesi tanı konuldukları gün ve birinci aydaki saf ses odyometri sonuçları kullanılarak yapıldı. Hastaların ortalama işitme eşikleri (SSO) 5001000-2000-4000 frekanslarının ortalamas1 kullanılarak hesaplandi (8).

Uygulanan tedavilerin etkinliği aşağıda açıklanan üç ayrı yöntem kullanılarak değerlendirildi.
1. İşitme kazanc1, tedavi öncesi SSO değerinden tedavi sonrası SSO çıkarılarak hesaplanmıştır.

2. İşitme geri dönüş yüzdesi, tedavi sonrasında SSO' larında $10 \mathrm{~dB}$ den fazla kazanç olan hastaların yüzdesi olarak hesaplanmıştır.

3. Furuhashi kriterleri ile hesaplanmıştır. Bu kriterler Tablo 1'de sunulmuştur (11).

Tablo 1. İyileşmeyi değerlendirmek için Furuhashi kriterleri.

\begin{tabular}{ll}
\hline \multicolumn{1}{l}{ İyileşme derecesi } & Kriter \\
Tam iyileşme & SSO $<20 \mathrm{~dB}$ ya da etkilenmemiş kulak ile aynı \\
Belirgin iyileşme & SSO daki iyileşme $>30 \mathrm{~dB}$ \\
Hafif iyileşme & SSO daki iyileşme $10 \mathrm{~dB}$ ile $30 \mathrm{~dB}$ arasında \\
İyileşme yok & SSO daki iyileşme $<10 \mathrm{~dB}$ \\
\hline SSO: $250-500-1000-2000-4000$ frekanslarındaki işitme eşiklerinin ortalamast. $d B:$ Desibel
\end{tabular}

\section{Ístatistiksel analiz}

Veriler SPSS v. 20.0 analiz programında incelendi. Kategorik veriler sayı ve yüzde olarak, sürekli veriler ortalama ve standart sapma olarak betimlendi. Verilerin normallik varsayımının incelenmesinde KolmogorovSmirnov testi kullanıldı. Bağımsız iki grubun karşılaştırılmasında Mann Whitney U testi, kategorik verilerin karşılaştırılmasında ki-kare testi kullanıldı. $\mathrm{p}<0,05$ değerleri istatistiksel olarak anlamlı kabul edildi.

\section{Bulgular}

Çalışmaya, dahil edilme kriterlerini sağlayan Grup 1 de 40, Grup 2 de 36 olmak üzere toplam 76 hasta dahil edilmiştir. 76 hastanın 28 'i $(\% 36,8)$ kadın 48 'i $(\% 63,2)$ erkektir.

İki grup demografik verileri (yaş, cinsiyet), işitme kaybı geçirilen kulağın tarafı, işitme kaybına vertigo ve tinnitusun eşlik edip etmemesi, hastaların mevcut sistemik hastalıkları (DM, HT), ÜSYE varlığı ve işitme azlığı şikâyetinin başlaması ile tedavi başlangıcı arasında geçen süre açısından karşılaştırıldığında, gruplar arasında istatistiksel olarak anlamlı fark saptanmadı (Tablo 2).

Tablo 2. Hastaların demografik ve klinik özellikleri

\begin{tabular}{|c|c|c|c|}
\hline & $\begin{array}{l}\text { Grup 1 } \\
(n=40)\end{array}$ & $\begin{array}{l}\text { Grup 2 } \\
(n=36)\end{array}$ & p değeri \\
\hline Yaş * & $48,80 \pm 16,29$ & $46,69 \pm 10,19$ & $0,283^{\dagger}$ \\
\hline Cinsiyet $(\mathbf{K} / \mathbf{E})$ & $12 / 28$ & $16 / 20$ & $0,192^{\ddagger}$ \\
\hline Taraf (să̌̆/sol) & $12 / 28$ & $13 / 23$ & $0,571^{*}$ \\
\hline Vertigo (var/yok) & $9 / 31$ & $6 / 30$ & $0,523^{\ddagger}$ \\
\hline Tinnitus (var/yok) & $35 / 5$ & $26 / 10$ & $0,095^{\star}$ \\
\hline $\begin{array}{l}\text { Semptom başlangıcı ile tedavi } \\
\text { arasında geçen süre (gün) }\end{array}$ & $5,98 \pm 2,93$ & $5,72 \pm 1,70$ & $0,879^{\dagger}$ \\
\hline Ek hastalık (var/yok) & $13 / 27$ & $26 / 10$ & $0,190^{\ddagger}$ \\
\hline ÜSYE (var/yok) & $6 / 34$ & $5 / 31$ & $0,891^{\ddagger}$ \\
\hline
\end{tabular}

K: Kadın, E: Erkek, ÜSYE: Üst solunum yolu enfeksiyonu, *: Ortalama \pm standart sapma olarak sunulmuştur, $\%$ : Mann-Whitney U testi, $¥$ : Ki-kare testi, 
Hastaların ortalama şikâyet başlangıç zamanı ile tedavi başlangıcı arasındaki süre grup $1 \mathrm{de}$ ortalama 5,98 2 ,93 gün grup 2 de ortalama $5,72 \pm 1,70$ gün olarak saptandi. İki grubun tedavi öncesindeki SSO ları karşılaştırıldığında; iki grup arasında istatistiksel olarak anlamlı fark bulunmadı $(\mathrm{p}=0,408)$ (Tablo 3). İki grubun tedavi sonrasi SSO karşılaştırıldığında; iki grubun SSO' ları arasında istatistiksel olarak anlamlı fark bulunmamıştır $(\mathrm{p}=0,703)$ (Tablo 3$)$.

İki grup arasında tedaviden görülen yararı değerlendirmek için ișitme kazançları, ișitme geri dönüş yüzdeleri ve Furuhashi kriterleri kullanarak karşılaştırıldığında her üç parametrede de iki grup arasinda istatistiksel olarak anlamlı fark bulunmamıştır (sırasıyla $\mathrm{p}=0,815, \mathrm{p}=0,626, \mathrm{p}=0,853)$ (Tablo 3 ve 4).

Tablo 3. Tedavi öncesi ve sonrası saf ses ortalama değerleri, işitme kazançları ve işitme geri dönüş yüzdesi

\begin{tabular}{|c|c|c|c|}
\hline & $\begin{array}{l}\text { Grup1 } \\
(n=40)\end{array}$ & $\begin{array}{l}\text { Grup 2 } \\
(\mathrm{n}=36)\end{array}$ & p değeri \\
\hline Tedavi öncesi SSO (dB)* & $50,75 \pm 30,74$ & $52,70 \pm 24,35$ & $0,408 \dagger$ \\
\hline Tedavi sonrası SSO $(\mathrm{dB}) *$ & $32,40 \pm 30,77$ & $32,18 \pm 21,84$ & $0,703 \dagger$ \\
\hline İşitme kazancı $(\mathrm{dB}) *$ & $18,34 \pm 15,42$ & $20,52 \pm 19,89$ & $0,815 \dagger$ \\
\hline $\begin{array}{l}\text { İşitme geri dönüş̧ yüzdesi } \\
\text { n, }(\%)\end{array}$ & $28(70,0)$ & $27(75)$ & $0,626^{*}$ \\
\hline
\end{tabular}

Tablo 4. Tedavi sonrasında Furuhashi kriterlerine göre iyileşmenin değerlendirilmesi.

\begin{tabular}{|c|c|c|c|}
\hline & $\begin{array}{l}\text { Grup1 } \\
\text { n (\%) }\end{array}$ & $\begin{array}{l}\text { Grup } 2 \\
\text { n (\%) }\end{array}$ & $p$ değeri \\
\hline Tam iyileşme & $16(40,0)$ & $12(33,3)$ & \multirow{4}{*}{$0,853^{*}$} \\
\hline Belirgin iyileşme & $5(12,5)$ & $6(16,7)$ & \\
\hline Hafif iyileşme & $11(27,5)$ & $12(33,3)$ & \\
\hline İyilesme yok & $8(20)$ & $6(16,7)$ & \\
\hline
\end{tabular}

\section{Tartışma}

AİK' da öne sürülmüş olan multiple etyolojik faktörler ve tedavi konusundaki farklı önermeler sebebiyle hali hazırda AİK tedavisinde kullanilan steroid tedavisi ve hiperbarik oksijen tedavisine ek olarak; antioksidanlar, anti-inflamatuvar ajanlar, vazodilatatörler, dekstran, vitaminler, antiviral ajanlar ve ganglion blokörleri gibi çeşitli tedavi protokolleri ilave edilmiştir $(6,12-14)$.

$\mathrm{Bu}$ tedavi protokollerinden antioksidanların tercih ediliş nedeni incelendiğinde; antioksidanların AİK 'da bozulmuş olabileceği düşünülen oksidan-antioksidan dengenin düzenlenebilmesi amaciyla kullanıldığ1 görülmüştür (7,12,15-17).

Reaktif oksijen türleri (ROT), reaktif azot türleri (RNT) ve serbest radikaller gibi normalde endojen antioksidanlar ile nonreaktif moleküllere dönüştürülerek yapım ve yıkımları bir denge içinde bulunan hücresel metabolitlerin, patolojik durumlarda düzeylerinin artarak oksidan-antioksidan dengenin bozulduğu ve bu durumun da odituar sistemde hasar ortaya çıkarabileceği, özellikle de diş tüy hücreleri, kohlea ve korti organının oksidatif strese en hassas yapılar olması ile ilişkili olarak AİK etiyolojisinde oksidanların önemli role sahip olduklarına dair çalışmalar mevcuttur $(7,12,15-20)$.

Serbest radikallerin AIK' daki rollerinin, işitme kaybının başlamasına sebep olan etiyolojik nedenden bağımsız olarak, patolojinin başlangıcını takiben erken dönemdeki artışları sonucu odituvar yapılara olan toksik etkileri ile patoloji oluşmasına 
katk1 yapmak ya da patoloji oluşumunu artırmak olduğu bildirilmiştir $(7,12,15-17)$.

Antioksidan ajanlar ise oksidatif stresi ortadan kaldırabilmek ve oksidan-antioksidan dengesini sağlamak amaciyla kullanılan önemli radikal temizleyicilerdir ve eksojen antioksidanların uygulanmasının, fazla miktarda oluşmuş olan serbest radikalleri etkisizleştirerek hücrelerdeki hasarı önleyebileceği ile ilgili çalışmalar mevcuttur $(7,21)$.

Hem antioksidan hem de bir anti-inflamatuvar olan, vücudumuzda eser element olarak bulunan çinko çok önemli nörofizyolojik ve patolojik süreçler içinde yer alır (22). Özellikle işitme sistemindeki (8. kranial sinir) sinapslarda etkili olması ve daha da önemlisi reaktif oksijen türlerine karşı ilk savunma hattını oluşturan $\mathrm{Cu} / \mathrm{Zn}$ süperoksit dismutaz (SOD) formunda koklear dokuda yüksek konsantrasyonda bulunması nedeniyle işitme fizyolojisi açısından önem taşımaktadır (2326).

Çinkonun kadmium ve pnömolizin ototoksisitesine karşı koruyucu etki gösterdiği ve çinko eksikliğinin salisilat ototoksisitesini artırdığı önceki hayvan çalışmalarında gösterilmiştir (27-29). Bunun yanında Shambaugh, ilerleyici SNIK'i olan hastalarda çinko eksikliğine dikkat çekmiştir ve iç kulak yapılarının çinko açısından zengin olması sebebiyle çinko eksikliği durumlarında SNIK, tinnitus ve dengesizlik meydana gelebileceğini öne sürmüştür $(9,10)$.

AİK tedavisi için çinkonun kullanımı araştırıldığında literatürde sadece iki çalışmaya ulaşılabilmiştir ve çinkonun AİK tedavisindeki etkinliği ile ilgili olarak bu çalışmalardaki sonuçlarda bir fikir birliği mevcut değildir. Bu çalışmalardan ilki Young ve ark tarafindan 2011 yılında yapılmış, steroid tedavisine çinko eklenmesinin AİK tedavisine etkisi incelenmiş ve steroid tedavisine çinko eklenmesinin iyileşmeyi artırdığg bildirilmiştir (8).

Çalışmamızın sonucunun, Young ve ark.' nın çalışmalarından farklı bulunmasının olası nedenlerinden birisinin hastalığın başlangıcı ile tedavi başlangıcı arasında geçen süre olabileceği düşünülmüştür. Çünkü serbest radikallerin antioksidanlar yoluyla non-reaktif moleküllere dönüştürülmesi ne kadar geç olursa tedaviden alınacak fayda o kadar azalabilmektedir. Young ve ark.'nın çalışmalarında tedavinin başlangıcı ile semptom başlangıcı arasındaki zaman 4,80 gün iken çalışmamızda 5,72 gündür (8). Ek olarak çalışmacıların da yazılarında belirttiği gibi, çinko tedavisi alan grupta hafif işitme kaybı olan hasta hiç yokken, çinko tedavisi almayan grupta hafif işitme kaybı olan hastalar da mevcuttur. Bu sebeple yazarlar, grupların işitme kaybının derecesi açısından da homejenize edilebilmesi amaciyla çinko tedavisi almayan grupta bulunan hafif işitme kayb1 olan hastaları dışlayıp yeniden istatistiksel analiz yaptıklarında, çinko tedavisi alan grupta tedaviden elde edilen yarar yine daha iyi olmuş ancak yeterli istatistiksel güce ulaşmamıştır. $\mathrm{Bu}$ durumun da çalışma sonuçlarında bir bias ortaya çıkarmış olması çok muhtemel görünmektedir ve bu durumu açıklığa kavuşturabilecek ek bir açıklama ya da ek önerme yapılmamıştır.

$\mathrm{Bu}$ konudaki ikinci çalışma ise Hunchaisri ve ark. tarafından yapılmış ve bu çalışmada ise steroid tedavisine çinko eklenmesinin iyileşmeye ilave bir fayda sağlamadığı sonucu bulunmuştur (30). Ancak bu çalışma incelendiğinde hasta sayısı çok kısıtlıdır, çalışma ve kontrol grubu toplam 30 kişiden oluşmaktadır. Çalışmacıların sonucunu etkileyebilecek diğer bir faktör ise tedaviye başlama süresidir. Antioksidanların AİK tedavisindeki savunulan muhtemel etki mekanizması; işitme kaybı hangi etyolojik nedene bağli olursa olsun patolojinin başlangıcındaki erken dönemde artan serbest radikalleri nötralize etmesidir (7,12,15-17). Ancak çalışmacıların çinko tedavisine başlama süresi $26,6 \pm 37,8$ gün gibi geç bir süredir ve bu durum da tedavi etkinliğinde azalmaya yol açmış olabilir.

Çinkonun AİK tedavisi için kullanıldığı çalışmalar incelendiğinde Young ve ark.' larının çalışmalarında iki ay süre ile $10 \mathrm{mg}$ çinko; günde iki kez 2 tablet kullanılmışken, Hunchaisri ve ark' larının çalışmasında ise 15 mg çinko bir ay boyunca yemekten sonra üç kez bir tablet olarak kullanılmıştır $(8,30)$. Biz 
de çalışmamızda literatürde yukarıda bahsedilmiş olan çalışmalardaki doz aralığına en yakın olması, günde tek doz ile kullanım avantajının olması nedeniyle çinko $50 \mathrm{mg}$ günde $1 \mathrm{kez} 1$ ay boyunca verilmiştir. Ancak literatürde AIK tedavisi için standardize edilmiş bir doz ve uygulama şekli ile ilgili bilgiye ulaşılamamıștır. Dolayısıyla AIIK tedavisinde çinko kullanımı ile ilgili olarak standardize edilmiş ideal bir doza yönelik daha kapsamlı ve prospektif çalışmaların yapılmasının konuyu aydınlatma açısından faydalı olabileceğini düşünmekteyiz.

Çalışmamızın retrospektif olarak yapılmış olması ve hastaların tedavi öncesi ve sonras1 kan çinko düzeylerinin hem iki grup arasında hem de sağlıklı popülasyonla karşılaştırılmamış olması çalışmanın kısıtlılıklarıdır. $\mathrm{Bu}$ kısitlılıkların giderildiği prospektif dizayn edilmiş, daha çok sayıda hastanın dahil edildiği, çok merkezli ve çinkonun kan düzeylerinin tedavi öncesi ve sonrası incelendiği çalışmaların yapılmasının hem bir antioksidan hem de anti-inflamatuvar olan çinkonun AİK tedavisinde yer alıp alamayacağı konusunda faydalı olabileceğini düşünmekteyiz.

\section{Sonuç}

AİK tedavisinde sistemik steroide çinko eklenmesi iyileşme parametrelerinde istatistiksel olarak anlamlı bir fark ortaya koymamıştır. Hem bir antioksidan hem de bir anti-inflamatuvar olduğu için çinkonun AİK' nın oluşumuna katkı sağlayabilecek muhtemel nedenlerin birden fazlasına eș zamanlı çözüm bulabileceği fikriyle teorik olarak faydalı olabileceği düşünülmekle birlikte hem tedavi ile ilişkili yeterli kanıt olmadığı hem de olası ilaç yan etkilerinden ve çoklu ilaç kullanımından kaçınmak amaciyla AİK tedavisinde kullanımının günümüz koşullarında önerilmemesinin daha uygun olduğunu düşünmekteyiz.

\section{KAYNAKLAR}

1. Hughes GB, Freedman MA, Haberkamp TJ et al. Sudden sensorineural hearing loss. Otolaryngol Clin North Am. 1996;29:393-405.

2. Eisenman D, Arts HA. Effectiveness of treatment for sudden sensorineural hearing loss. Arch Otolaryngol Head Neck Surg. 2000;126:1161-4.

3. Quaranta N, Ramunni A, De Luca C et al. Endothelial progenitor cells in sudden sensorineural hearing loss. Acta Otolaryngol. 2011;131:347-50.

4. Whitaker S. Idiopathic sudden hearing loss. Am J Otol.1980;1:180-3.

5. Robert JS, Sujana SC, Sanford MA et al. Clinical Practice Guideline:Sudden Hearing Loss. Otolaryngol Head Neck Surg. 2012;146:1-35.

6. Sujana SC, Betty ST, Seth RS et al. Clinical Practice Guideline: Sudden Hearing Loss (Update) Executive Summary. Otolaryngol Head Neck Surg. 2019;61:195-210.

7. Ibrahim I, Zeitouni A, Da Silva SD. Effect of Antioxidant Vitamins as Adjuvant Therapy for Sudden Sensorineural Hearing Loss: Systematic Review Study. Audiol Neurootol. 2018;23:1-7.

8. Yang CH, Tse Ko M, Peng JP et al. Zinc in the treatment of idiopathic sudden sensorineural hearing loss. Laryngoscope. 2011;121:617-21.

9. Shambaugh GE Jr. Zinc and presbycusis. Am J Otol. 1985;6:116-7.

10. Shambaugh GE Jr. Zinc for tinnitus, imbalance, and hearing loss in the elderly. Am J Otol. 1986;7:476-7.

11. Nakashima T, Sato H, Gyo K et al. Idiopathic sudden sensorineural hearing loss in Japan. Acta Otolaryngol. 2014;134:1158-63.

12. Joachims HZ, Segal J, Golz A et al. Antioxidants in treatment of idiopathic sudden hearing loss. Otol Neurotol. 2003;24:572-5.

13. Toroslu T, Erdoğan H, Çağlar Ö et al. Comparison of different treatment methods for idiopathic sudden sensorineural hearing loss. Turk Arch Otorhinolaryngol. 2018;56:226-32.

14. Körpinar S, Alkan Z, Yiğit $\mathrm{O}$ et al. Factors influencing the outcome of idiopathic sudden sensorineural hearing loss treated with hyperbaric oxygen therapy. Eur Arch Otorhinolaryngol. 2011;268:41-7.

15. Clerici WJ, DiMartino DL, Prasad MR. Direct effects of reactive oxygen species on cochlear outer hair cell shape in vitro. Hear Res. 1995;84:30-40.

16. Nordang L, Anniko M. Nitro-L-arginine methyl ester: a potential protector against gentamicin ototoxicity. Acta Otolaryngol. 2005;125:1033-8.

17. Kaya H, Karaman Koç A, Sayın I et al. Vitamins $\mathrm{A}, \mathrm{C}$, and $\mathrm{E}$ and selenium in the treatment of idiopathic sudden sensorineural hearing loss. Eur Arch Otorhinolaryngol. 2015;272:1119-25.

18. Rybak LP, Whitworth C, Somani S. Application of antioxidants and other agents to prevent cisplatin ototoxicity. Laryngoscope. 1999;109:1740-4. 
19. Takumida M, Anniko M. Functional significance of nitric oxide in the inner ear. In Vivo. 2004; 18:345-50.

20. Darrat I, Ahmad N, Seidman K et al. Auditory research involving antioxidants. Curr Opin Otolaryngol Head Neck Surg. 2007;15:358-63.

21. Young IS, Woodside JV. Antioxidants in health and disease. J Clin Pathol. 2001;54:176-86.

22. Sensi SL, Paoletti P, Bush AI et al. Zinc in the physiology and pathology of the CNS. Nat Rev Neurosci. 2009;10:780-91.

23. Zirpel L, Parks TN. Zinc inhibition of group I mGluR-mediated calcium homeostasis in auditory neurons. J Assoc Res Otolaryngol. 2001;2:180-7.

24. Rarey KE, Yao X. Localization of $\mathrm{Cu} / \mathrm{Zn}-\mathrm{SOD}$ and Mn-SOD in the rat cochlea. Acta Otolaryngol. 1996;116:833-5.

25. Karabulut H,Gülay MS. Antioksidanlar. MAE Vet Fak Derg. 2016;1:65-76.

26. 26.Sen S, Chakraborty R, Sridhar C et al. Free radicals, antioxidants, diseases and phytomedicines: Current status and future prospect. Int J Pharm Sci Res. 2010;3:91-100.

27. Gunther T, Rebentisch E, Vormann J et al. Enhanced ototoxicity of gentamicin and salicylate caused by $\mathrm{Mg}$ deficiency and $\mathrm{Zn}$ deficiency. Biol Trace Elem Res. 1988;16:43-50.

28. Franco-Vidal V, Beurg M, Darrouzet V et al. Zinc protection against pneumolysin toxicity on rat cochlear hair cells. Audiol Neurootol. 2008;13:6570 .

29. Agirdir BV, Bilgen I, Dinc O et al. Effect of zinc ion on cadmium induced auditory changes. Biol Trace Elem Res. 2002;88:153-63.

30. 30.Hunchaisri N, Chantapant S, Sirirattanapan J. Effectiveness of oral zinc supplementation in the treatment of idiopathic sudden sensorineural hearing loss (ISSNHL). J Med Assoc Thai. 2015;98:400-7. 